\title{
Oxytocin receptor gene expression in rat uterus: regulation by ovarian steroids
}

\author{
T Murata, E Murata, C-X Liu, K Narita, K Honda and T Higuchi \\ Department of Physiology, Fukui Medical University, 23-3 Shimoaizuki, Matsuoka, Fukui 910-1193, Japan \\ (Requests for offprints should be addressed to T Murata; Email: muratat@fmsrsa.fukui-med.ac.jp)
}

\begin{abstract}
The present study was designed to investigate a possible role for ovarian steroids in the regulation of rat uterine oxytocin receptor (OTR) mRNA expression before labour. By using a competitive RT-PCR system, we have previously reported that parturition was associated with high levels of uterine OTR mRNA in all the animals examined. On the other hand, near term, some rats showed high OTR mRNA levels while others did not. We therefore examined the changes in OTR mRNA expression before and during prostaglandin $\mathrm{F}_{2 \alpha}\left(\mathrm{PGF}_{2 \alpha}\right)$ induced parturition; a paradigm adopted to reduce the variation in the onset of parturition. Injection of $\mathrm{PGF}_{2 \alpha}$ on day 18 of pregnancy significantly increased OTR mRNA expression in all the rats within $24 \mathrm{~h}$ of treatment, suggesting that the variation in OTR mRNA levels during spontaneous parturition may be due to the difference in the timing of the onset of parturition. The increase in OTR mRNA was significantly abolished by injection of the anti-oestrogen compound, tamoxifen. The stimulatory action of oestrogen on OTR mRNA expression was then
\end{abstract}

examined in the presence or absence of ovarian factors. Pregnant rats were ovariectomized (OVX) or shamoperated on day 18 of pregnancy and either oestrogen or vehicle was administered $6 \mathrm{~h}$ after the surgical operation. Oestrogen increased OTR mRNA significantly in OVX rats $18 \mathrm{~h}$ after administration compared with shamoperated animals. Moreover, ovariectomy alone on day 18 of pregnancy increased OTR mRNA expression to a level which reached statistical significance $24 \mathrm{~h}$ after the operation. In addition, oestrogen treatment increased OTR mRNA levels in OVX virgin rats in which progesterone tubes were implanted for 1 week and removed $6 \mathrm{~h}$ before oestrogen injection. The stimulatory effect of oestrogen was not observed in rats in which the progesterone tubes were implanted for 1 week and not removed. These results suggest that the decline of progesterone is necessary for the expression of the stimulatory effects of oestrogen on uterine OTR mRNA.

Journal of Endocrinology (2000) 166, 45-52

\section{Introduction}

Oxytocin (OT) was initially isolated as a neurohypophysial hormone which stimulates the contraction of the myometrium and myoepithelium to facilitate parturition and milk ejection respectively, and is considered to act on various reproductive functions as a neuroregulator or in a paracrine manner in the ovary or the uterus (Higuchi 1995). In the uterus, the near-term myometrium is extremely sensitive to OT and this increased uterine responsiveness to OT occurs in parallel with alteration in the number of uterine OT-binding sites in rats (Soloff et al. 1979, Fuchs et al. 1983), humans (Fuchs et al. 1984), rabbits (Maggi et al. 1988, 1991) and sheep (Wathes et al. 1996a, Wu et al. 1996a). The exact factors or sequence of events in late pregnancy which lead to the initiation of parturition and change in the dynamics of the OT-binding sites are not clearly understood at present. An understanding of the various physiological roles of OT, especially in the initiation and progress of parturition, requires an elucidation of the mechanisms regulating uterine OT-receptor (OTR) synthesis near term.

Following cloning of the rat OTR gene (Rozen et al. 1995), several studies employing various methods have been reported on the regulation of uterine OTR mRNA expression during pregnancy and parturition (Larcher et al. 1995, Liu et al. 1996, Ou et al. 1998). A consistent finding among these studies is an increased OTR mRNA expression during delivery; however, the exact timing of the OTR mRNA increase is not still clearly understood. In two separate studies by Larcher et al. (1995) and Ou et al. (1998), no significant increase in OTR mRNA expression was observed before delivery. In our earlier study, using a competitive reverse transcription (RT)-PCR system, all parturient rats showed high levels of uterine OTR mRNA; while some near-term rats showed high OTR mRNA levels, others did not (Liu et al. 1996). In order to further understand how OTR mRNA expression is 
regulated and how this is related to the onset of parturition, it is necessary to define why there is a variation in the increase in OTR mRNA expression before spontaneous parturition. One possible explanation is the difference in the timing of the onset of parturition, because rats used in our laboratory routinely start delivery from day 22 to day 23 of pregnancy. We have therefore examined the change in OTR mRNA expression before and during parturition induced by prostaglandin $\mathrm{F}_{2 \alpha}\left(\mathrm{PGF}_{2 \alpha}\right)$ to reduce the variation in the onset of parturition.

Ovarian steroids, oestrogen and progesterone have been reported to be involved in the regulation of OT function. In this context, oestrogen stimulated the number of uterine OT-binding sites (Soloff 1975, Fuchs et al. 1983, Soloff et al. 1983) and OTR mRNA expression in ovariectomized (OVX) virgin rats (Larcher et al. 1995, Liu et al. 1996). Concomitant injection of progesterone with oestrogen suppressed the stimulatory effect of oestrogen on OT binding (Soloff 1975, Fuchs et al. 1983, Soloff et al. 1983), probably via a direct effect of progesterone on the uterine OTR in part (Grazzini et al. 1998), but did not inhibit its effect on OTR mRNA expression (Larcher et al. 1995, Liu et al. 1996). On the other hand, treatment with the anti-progesterone compound, RU486, increased OTR mRNA expression in the rat uterus (Fang et al. 1997). The increased expression of OTR mRNA resulting from ovariectomy in late pregnancy was inhibited by progesterone injection (Ou et al. 1998). Thus, progesterone appears to be involved in the regulation of OTR mRNA expression, but its effect on the role of oestrogen in OTR mRNA expression is not clear. In this study, we have examined further the involvement of progesterone in the stimulatory action of oestrogen on OTR mRNA expression in both pregnant and OVX virgin rats.

\section{Materials and Methods}

\section{Animals}

Adult female Wistar rats (body weight 180-220 g) were obtained from Japan SLC (Hamamatsu, Japan). They were kept in an environmentally controlled room (temperature $23 \pm 3{ }^{\circ} \mathrm{C}$; lights on $0500-1900 \mathrm{~h}$ in experiments $1-3$, lights on $0800-2000 \mathrm{~h}$ in experiment 4). They were allowed free access to tap water and pelleted rat food (NMF; Oriental Yeast Co. Ltd, Tokyo, Japan). Oestrous cycles were monitored by vaginal smears taken daily in the morning (0900-1000 h). Pro-oestrous females were allowed to mate with conspecific males housed under similar conditions and this was designated day 1 of pregnancy if spermatozoa were present in the vaginal smear the following morning.

\section{Experiment 1: effects of $P G F_{2 a}$ in pregnant rats}

At $1100-1130 \mathrm{~h}$ on day 18 of pregnancy, the rats were injected s.c. with $500 \mu \mathrm{g} \mathrm{PGF}_{2 \alpha}$ (Wako Chemicals Co.,
Osaka, Japan) in $0.2 \mathrm{ml} 99 \%$ ethanol or vehicle alone. The rats delivered within 29 to $35 \mathrm{~h}$ after the $\mathrm{PGF}_{2 \alpha}$ treatment. The PGF ${ }_{2 \alpha}$-treated rats were killed $6(n=3), 12(n=4), 18$ $(n=6), 24(n=6), 30(n=6)$ and $54 \mathrm{~h}(n=3)$ after the treatment and during delivery $(n=7)$. Control rats $(n=4)$ received vehicle alone and were killed $29-35 \mathrm{~h}$ after the treatment (day 19 of pregnancy). The uterine horns were quickly dissected, immediately frozen in liquid nitrogen and stored at $-70{ }^{\circ} \mathrm{C}$ until RNA extraction.

\section{Experiment 2: effects of tamoxifen in $\mathrm{PGF}_{2 a^{- \text {treated }}}$ pregnant rats}

At $1100-1130 \mathrm{~h}$ on day 18 of pregnancy, the rats were injected s.c. with $500 \mu \mathrm{g} \mathrm{PGF}_{2 \alpha}$ followed by $250 \mu \mathrm{g}$ tamoxifen (Sigma, St Louis, MO, USA) in $0.25 \mathrm{ml}$ sesame oil $6 \mathrm{~h}$ later $(n=6)$. Control animals were injected with $\mathrm{PGF}_{2 \alpha}$ /sesame oil $(n=8)$ and ethanol/sesame oil $(n=4)$. The rats were killed at $1100-1130 \mathrm{~h}$ on day 19 of pregnancy.

\section{Experiment 3: effects of ovariectomy on oestrogen action in pregnant rats}

On day 18 of pregnancy, the rats were ovariectomized or sham-operated under ether anaesthesia at 1030-1200 h and were then given an s.c. injection of $17 \beta$-oestradiol (Sigma; $12.5 \mu \mathrm{g}$ in $0.2 \mathrm{ml}$ sesame oil) or vehicle alone at $1700-1730 \mathrm{~h}$ ( $n=5$ each group). The rats were killed at $1100-1200 \mathrm{~h}$ on day 19 of pregnancy.

\section{Experiment 4: effects of progesterone on oestrogen action in virgin $O V X$ rats}

Virgin rats were ovariectomized under ether anaesthesia 2 weeks before the steroid treatments and then divided into six groups (groups 1-6, $n=5$ ). Silicon tubing (outside diameter, $3 \mathrm{~mm}$; inside diameter, $2 \mathrm{~mm}$ ) was filled with crystalline progesterone (Nacalai Tesque Inc., Kyoto, Japan), sealed with silicon glue and incubated with phosphate-buffered saline (pH 7.4) for $48 \mathrm{~h}$. Groups 1 and 2 were implanted with three $30 \mathrm{~mm}$ empty tubes (day 1 ). Groups 3-6 were implanted with tubes containing progesterone (day 1). All the rats were then anaesthetised with ether at $1100-1130 \mathrm{~h}$ on day 8 , and the tubes were removed from animals in groups 1-4 but not from animals in groups 5 and 6 . The rats in groups 2,4 and 6 were given an s.c. injection of $17 \beta$-estradiol $(12.5 \mu \mathrm{g}$ in $0.2 \mathrm{ml}$ sesame oil) at $1700-1730 \mathrm{~h}$ on day 8 , and the rats in groups 1,3 and 5 were given vehicle alone. All the rats were killed at $1100-1200 \mathrm{~h}$ on day 9.

\section{Competitive RT-PCR analysis}

Complementary DNA synthesis, PCR amplification and analysis of PCR products were performed as described 
previously (Liu et al. 1996). Briefly, uterine tissue (50$100 \mathrm{mg}$ ) was homogenised with TRIzol reagent (Gibco BRL, Gaithersburg, MD, USA). Total RNA samples were prepared according to the acid guanidinium thiocyanatephenol-chloroform extraction method (Chomczynski \& Sacchi 1987) using TRIzol reagent and treated with RNase-free DNaseI (Gibco BRL) to exclude genomic DNA. The quantity of total RNA was assessed with a spectrophotometer at a wave length of $260 \mathrm{~nm}$. Total RNA $(1 \mu \mathrm{g})$ of samples and serial diluted total RNA from uterus during labour $(1000,250,62.5,15 \cdot 6$ and $3.9 \mathrm{ng} /$ tube) as standards, together with $1 \times 10^{7}$ copies of internal cRNA, were reverse transcribed with 200 U SuperScript II reverse transcriptase according to the supplier's manual (Gibco BRL) and 10 pmol 9-mer random primer. All the samples and the standards in each experiment were assayed in a single run. Internal cRNA was constructed by the insertion of a $106 \mathrm{bp}$ PvuII/SmaI fragment of pUC19 plasmid into a StuI site of $161 \mathrm{bp}$ OTR DNA. Both cDNAs reverse-transcribed from native OTR mRNA and internal cRNA were amplified with same primers, 5'CGATTGCTGGGCGGTCTT-3' and 5'-CCGCCGCT GCCGTCTTGA-3', to $161 \mathrm{bp}$ and 267 bp respectively. The PCR amplification was carried out in PCR buffer $(50 \mathrm{mM} \mathrm{KCl}, 2 \mathrm{mM} \mathrm{MgCl}$ and $20 \mathrm{mM}$ Tris-HCl, $\mathrm{pH}$ 8.4), with $0.2 \mu \mathrm{mol}$ primers and $2.5 \mathrm{U}$ Taq polymerase (Gibco BRL) in a total volume of $50 \mu \mathrm{l}$ for 35 cycles consisting of denaturation at $94^{\circ} \mathrm{C}$ for $30 \mathrm{~s}$, annealing at $62{ }^{\circ} \mathrm{C}$ for $20 \mathrm{~s}$ and extension at $72{ }^{\circ} \mathrm{C}$ for $1 \mathrm{~min}$ after the initial denaturation at $94^{\circ} \mathrm{C}$ for $10 \mathrm{~min}$. Amplification was completed with an additional extension step at $72{ }^{\circ} \mathrm{C}$ for 10 $\mathrm{min}$. The PCR products were separated on $2 \%$ agarose gel containing ethidium bromide $(0.5 \mu \mathrm{g} / \mathrm{ml})$ and fluorescence density was analysed using NIH Image software. The linear standard curve was obtained and no band was detected when the PCR reaction was carried out with total RNA sample without the reverse transcription to check contamination with genomic DNA or non-specific reaction in each experiment. The ratio of native OTR mRNA-derived DNA (161 bp) to internal cRNAderived DNA (267 bp) of each sample was obtained and calibrated from a standard curve as the amount of standard total mRNA. Data are expressed as the relative amounts (\%) by dividing the value of each sample with the mean value of the corresponding control group.

\section{Progesterone assay}

Serum progesterone concentrations were measured using double-antibody assay kits purchased from Daiichi Radioisotope Laboratories Ltd (Tokyo, Japan) in duplicate on ether extracts of serum obtained from trunk blood.

\section{Statistical analysis}

The data are expressed as the mean \pm s.E. and evaluated statistically using Student's t-test or one-way ANOVA

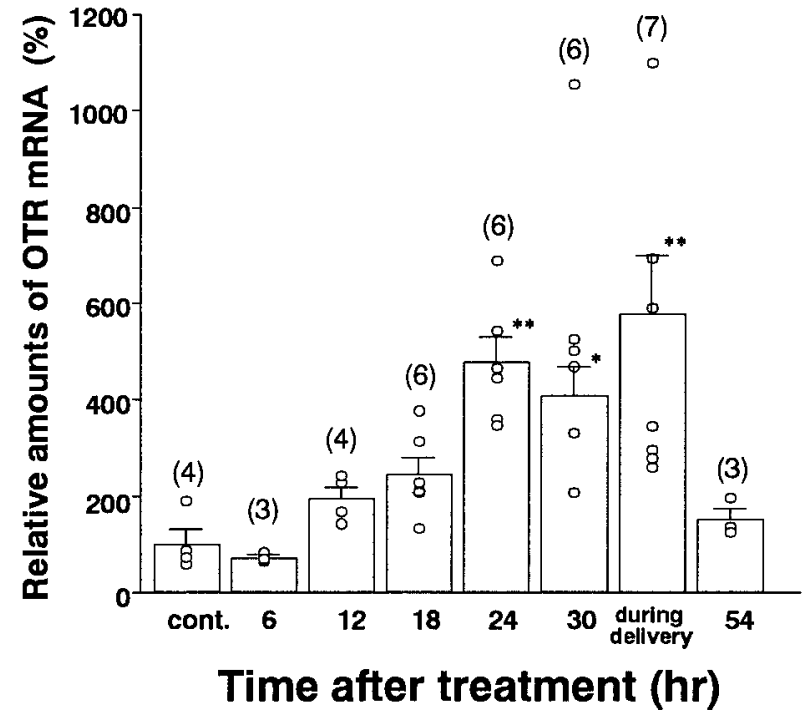

Figure 1 Relative amounts of uterine OTR mRNA levels in $\mathrm{PGF}_{2 \alpha}$-treated pregnant rats. Circles and bars indicate individual and mean values respectively. Rats were injected with PGF $_{2 \alpha}$ ( $500 \mu$ g, s.c.) at $1100-1130 \mathrm{~h}$ on day 18 of pregnancy. The value of control (cont.) rats which were treated with vehicle and killed 29-35 h after the treatment was defined as $100 \%$. Values shown in parentheses are the number in each group. ${ }^{\star} P<0 \cdot 05,{ }^{*} P<0 \cdot 01$ compared with control group (Scheffe's F test).

followed by Scheffes's F test or Fisher's Protected Least Significant Difference (PLSD) test.

\section{Results}

Experiment 1: effect of $P G F_{2 a}$ in pregnant rats

The effects of $\mathrm{PGF}_{2 \alpha}$ treatment on OTR mRNA expression in pregnant rats were examined. There was an increase in the OTR mRNA level $12 \mathrm{~h}$ and $18 \mathrm{~h}$ after treatment. This increase in OTR mRNA expression reached a significant level $24 \mathrm{~h}$ after treatment and was maintained until during labour (Fig. 1). Serum progesterone levels began to decline from $12 \mathrm{~h}$ after the $\mathrm{PGF}_{2 \alpha}$ treatment and were maintained at low levels up to $30 \mathrm{~h}$ after the treatment (Table 1).

Experiment 2: effect of tamoxifen in $P G F_{2 a}$-treated pregnant rats

Next, the involvement of oestrogen in the increase in OTR mRNA levels after PGF $_{2 \alpha}$ treatment was examined. Tamoxifen, an anti-oestrogenic agent, was administered $6 \mathrm{~h}$ after the $\mathrm{PGF}_{2 \alpha}$ treatment. The $\mathrm{PGF}_{2 \alpha}$ treatment increased $(P<0 \cdot 01)$ OTR mRNA level at $24 \mathrm{~h}$ after treatment and this increase was significantly abolished 
Table 1 Serum progesterone levels after $\mathrm{PGF}_{2 \alpha}$ treatment in pregnant rats. Data are expressed as the mean \pm S.E. $(n \geq 3)$

\begin{tabular}{cl} 
& \multicolumn{1}{l}{ Serum progesterone $(\mathrm{ng} / \mathrm{ml})$} \\
\cline { 2 - 2 } Treatment $^{\mathrm{a}}$ & \\
PGF $_{2 \alpha}$ & \\
$6 \mathrm{~h}$ & $28 \cdot 0 \pm 5 \cdot 19$ \\
$12 \mathrm{~h}$ & $13 \cdot 6 \pm 3 \cdot 99$ \\
$18 \mathrm{~h}$ & $7 \cdot 43 \pm 1 \cdot 71$ \\
$24 \mathrm{~h}$ & $5 \cdot 35 \pm 0.97$ \\
$30 \mathrm{~h}$ & $4 \cdot 58 \pm 0 \cdot 93$ \\
Vehicle & \\
$30 \mathrm{~h}$ & $29 \cdot 2 \pm 8.95$
\end{tabular}

${ }^{a}$ Animals were injected s.c. with $\mathrm{PGF}_{2 \alpha}(500 \mu \mathrm{g})$ or vehicle at $1100-1130 \mathrm{~h}$ on day 18 of pregnancy.

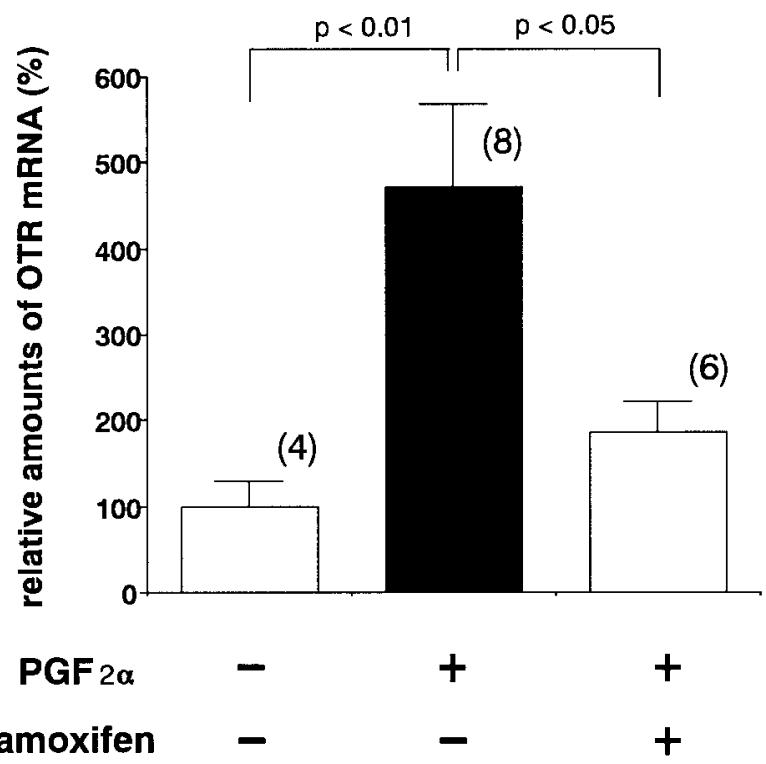

Figure 2 Effect of tamoxifen on $\mathrm{PGF}_{2 \alpha}$-induced increase of uterine OTR mRNA levels in pregnant rats. PGF $\mathrm{PG}_{2 \alpha}(500 \mu$ g, s.c.) was administered at $1100-1130 \mathrm{~h}$ on day 18 of pregnancy and tamoxifen $(250 \mu \mathrm{g}$, s.c.) or vehicle was administered $6 \mathrm{~h}$ after the $\mathrm{PGF}_{2 \alpha}$ treatment. Rats were killed $24 \mathrm{~h}$ after the $\mathrm{PGF}_{2 \alpha}$ treatment. Data are expressed as the mean \pm S.E. The value of control rats treated with vehicle alone was defined as $100 \%$. Values shown in parentheses are the number in each group. Scheffe's F test was used for comparison of values.

$(P<0 \cdot 05)$ by tamoxifen injection (Fig. 2). There was no significant difference between the control and the tamoxifen-treated rats.

\section{Experiment 3: effect of ovariectomy on oestrogen action in pregnant rats}

The stimulatory action of oestrogen on OTR mRNA expression was examined with or without ovarian factors. Rats were ovariectomized or sham-operated on day 18 of pregnancy. Oestrogen injection $6 \mathrm{~h}$ after the operation did

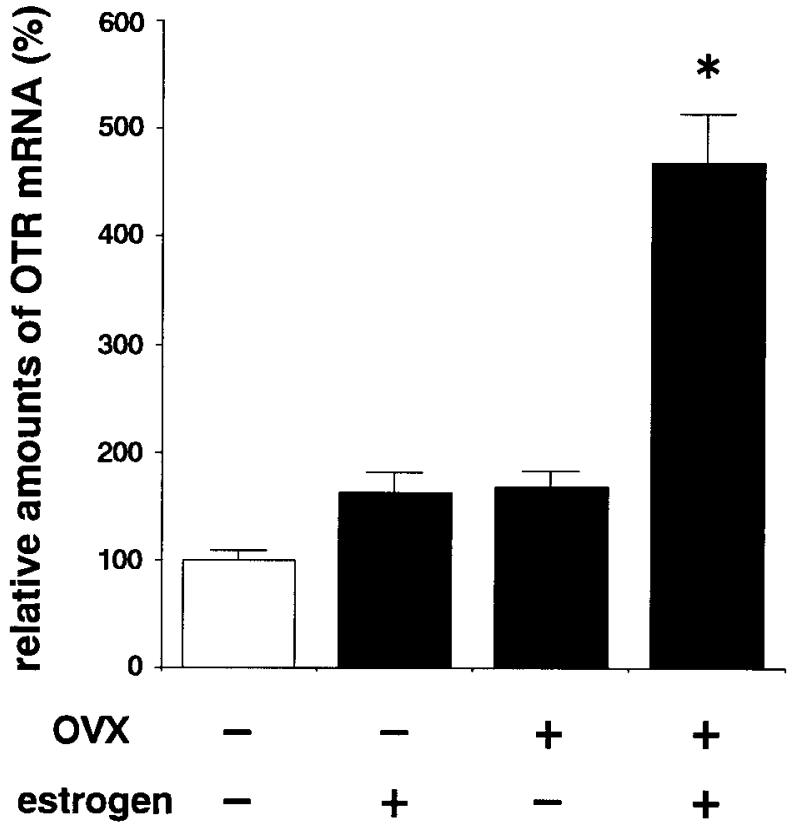

Figure 3 Effects of oestrogen on uterine OTR mRNA levels in OVX pregnant rats. Pregnant rats were ovariectomized or sham-operated at 1030-1200 h on day 18 of pregnancy and oestrogen (17 $\beta$-estradiol, $12.5 \mu \mathrm{g}$, s.c.) or vehicle was administered $6 \mathrm{~h}$ after the operation. Rats were killed at $1100-1200 \mathrm{~h}$ on day 19 of pregnancy. Data are expressed as the mean \pm S.E. $(n=5)$. The value of control rats was defined as $100 \%$. ${ }^{*} P<0.05$ compared with the other three groups (Fisher's PLSD test).

not significantly increase OTR mRNA in sham-operated rats compared with the vehicle-treated rats (Fig. 3). Oestrogen treatment in OVX rats significantly increased OTR mRNA compared with either OVX or shamoperated rats without oestrogen treatment (Fig. 3). No significant difference $(P=0.08)$ was detected between the two vehicle-treated groups, the sham-operated rats and OVX rats without oestrogen treatment, when the data were analysed among the four groups using the PLSD test (Fig. 3). However, since there appeared to be a difference between these two vehicle-treated groups, the difference was re-examined between the groups using Student's $t$-test. This analysis revealed that ovariectomy in pregnant rats on day 18 alone had a small stimulatory effect on OTR mRNA expression (sham-operated $100 \pm 5 \cdot 1$ $(n=9)$ versus OVX $165 \cdot 8 \pm 13 \cdot 1(\%)(n=10))$.

\section{Experiment 4: effects of progesterone on oestrogen action in virgin $\mathrm{OVX}$ rats}

To understand the involvement of progesterone in the facilitation of oestrogen action after ovariectomy in pregnant rats, the effects of progesterone withdrawal on oestrogen action in OVX virgin rats were examined. The administration of oestrogen significantly increased OTR 


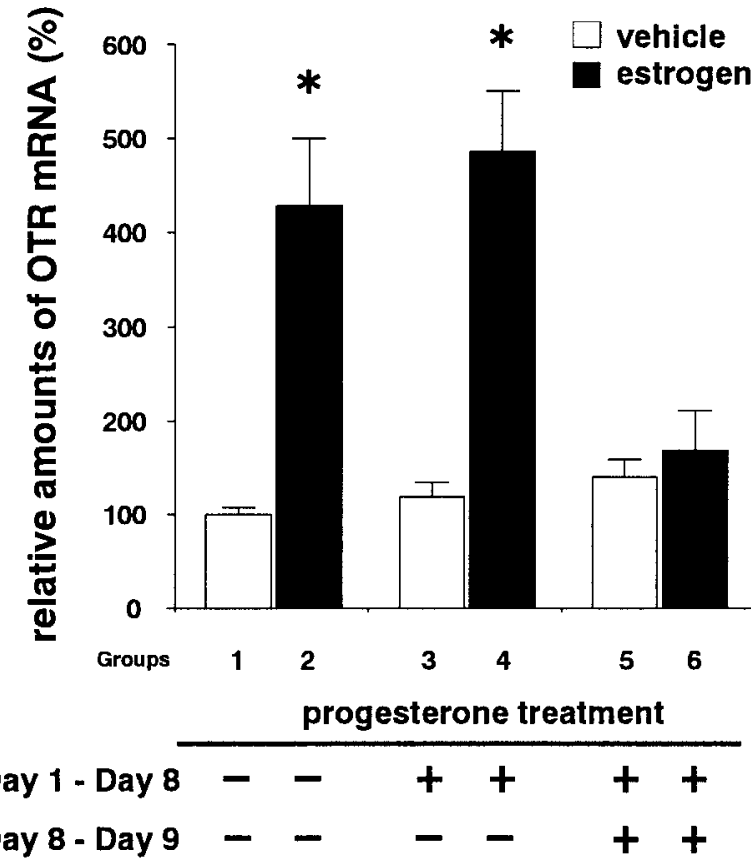

Figure 4 Effects of progesterone on the stimulatory action of oestrogen in uterine OTR mRNA levels in OVX virgin rats. OVX virgin rats were divided into six groups (groups 1-6). Groups 1 and 2 were implanted with three empty tubes, and groups 3-6 were implanted with three tubes containing progesterone (day 1 ). The tubes were then removed at $1100-1130 \mathrm{~h}$ on day 8 in groups 1-4 and were not removed in groups 5 and 6 . The rats in groups 2,4 and 6 were given an s.c. injection of oestrogen ( $17 \beta$-estradiol, $12.5 \mu \mathrm{g})$ at $1700-1730 \mathrm{~h}$ on day 8 , and the rats in groups 1,3 and 5 were given vehicle alone. The rats were killed at 1100-1200 $\mathrm{h}$ on day 9. Data are expressed as the mean \pm S.E. $(n=5)$. The value of group 1 was defined as $100 \%$. ${ }^{*} P<0 \cdot 05$ compared with group 1 (Fisher's PLSD test).

mRNA levels in control rats implanted with empty tubes. In rats in which progesterone tubes were implanted for 1 week and removed $6 \mathrm{~h}$ before the oestrogen injection, the oestrogen treatment also increased OTR mRNA levels to the same level as that in the control rats. On the other hand, the stimulatory effect of oestrogen was not observed in rats in which the progesterone tubes were implanted for 1 week without removal (Fig. 4). Serum progesterone levels of rats in each group at death are shown in Table 2.

\section{Discussion}

In a previous study (Liu et al. 1996), we reported that in late pregnant rats (on the late evening of day 21 of pregnancy), variable levels of uterine OTR mRNA were observed among the animals prior to spontaneous delivery. On the other hand, high levels of uterine OTR mRNA were observed in all parturient animals (on days 22 and 23 of pregnancy). To understand the relationship between the onset of parturition and the regulation of OTR expression, it is necessary to define the variation in OTR mRNA expression observed on day 21 of pregnancy. One possibility is that the variation results from the difference in the timing of the onset of parturition from one animal to the other. To compensate for this, it is necessary to adopt a paradigm in which the variation in the timing of the onset of parturition is kept to reasonably low limits. The change in OTR mRNA expression before and during parturition induced by $\mathrm{PGF}_{2 \alpha}$ to reduce the variation in the onset of parturition was therefore examined. Delivery induced by $\mathrm{PGF}_{2 \alpha}$ was routinely observed $29-35 \mathrm{~h}$ after treatment, while spontaneous delivery was observed from the evening of day 22 of pregnancy until the morning of day 23 (Liu et al. 1996). The present study demonstrated that OTR mRNA increased significantly within $24 \mathrm{~h}$ after $\mathrm{PGF}_{2 \alpha}$ treatment, with all the rats showing high levels of OTR mRNA at $24 \mathrm{~h}$. Since the variation observed in late pregnancy before spontaneous delivery was not observed before $\mathrm{PGF}_{2 \alpha}$-induced delivery, these results suggest that the variation observed in late pregnancy before spontaneous delivery may be due to the difference in the timing of parturition, and that the OTR mRNA levels change in a similar time-course once the mechanism regulating the onset of the parturition is turned on. Furthermore, $\mathrm{PGF}_{2 \alpha}$-treated pregnant rats (which showed a smaller limit of variation in OTR mRNA expression compared with the observation in spontaneously parturient

Table 2 Serum progesterone levels in rats treated with progesterone. Data are expressed as the mean \pm S.E. $(n=5)$

\section{Treatment}

\begin{tabular}{llll}
\hline Day 1-day 8 & Day 8-day 9 & & Serum progesterone $(\mathrm{ng} / \mathrm{ml})$ \\
${$\cline { 1 - 1 }$^{\mathrm{a}}} }$ & - & & $2 \cdot 22 \pm 1 \cdot 06$ \\
Progesterone tubes $^{\mathrm{b}}$ & & - & $6 \cdot 79 \pm 1 \cdot 51$ \\
Progesterone tubes $^{\text {Progesterone tubes }}{ }^{\mathrm{c}}$ & & $16 \cdot 8 \pm 1 \cdot 28$
\end{tabular}

Virgin rats were ovariectomized 2 weeks before the treatments and were implanted with empty tubes or tubes containing progesterone (progesterone tubes) (day 1). a Empty tubes were implanted and removed at $1100-1130 \mathrm{~h}$ on day 8 ; ${ }^{b}$ progesterone tubes were implanted and removed on day 8 ; cprogesterone tubes were implanted and not removed. All the rats were killed at $1100-1200 \mathrm{~h}$ on day 9 and blood samples were collected from trunk blood. 
rats) may constitute a useful model to understand the mechanism(s) which are involved in the regulation of parturition.

Oestrogen treatment has been reported to cause increased uterine OTR mRNA in OVX virgin rats (Larcher et al. 1995, Liu et al. 1996). To ascertain whether endogenous oestrogen is actually involved in the increased OTR mRNA expression during parturition, the effect of the anti-oestrogenic agent, tamoxifen, on OTR mRNA levels in $\mathrm{PGF}_{2 \alpha}$-treated rats was examined. Tamoxifen treatment suppressed the increase in OTR mRNA levels observed at $24 \mathrm{~h}$ after $\mathrm{PGF}_{2 \alpha}$ treatment on day 18 of pregnancy, suggesting that the increased endogenous oestrogen levels after luteolysis is necessary for the induction of OTR mRNA during parturition. In addition, this observation indicated that the $\mathrm{PGF}_{2 \alpha}$-induced increase in OTR mRNA levels is mediated by endogenous oestrogen, but not by the direct effect of $\mathrm{PGF}_{2 \alpha}$ per se.

The importance of the decline in progesterone levels in late pregnancy for the action of oestrogen in OT expression in the hypothalamus of female rats (Crowley et al. 1995) and the induction of maternal behaviour (Bridges 1984) has been reported. However, a concomitant administration of progesterone with oestrogen does not suppress the stimulatory effect of oestrogen on OTR mRNA expression in OVX non-pregnant rats (Larcher et al. 1995, Liu et al. 1996), although progesterone administration prolongs pregnancy and suppresses the increase in OTR mRNA expression (Ou et al. 1998). Thus, the effect of progesterone on the role of oestrogen in the expression of OTR mRNA and whether the withdrawal of progesterone is necessary for the action of oestrogen on OTR mRNA expression have not yet been clarified. To investigate the nature of the effect of progesterone withdrawal on oestrogen action, we therefore examined the effects of ovariectomy (on day 18 of pregnancy) on oestrogeninduced OTR mRNA expression in pregnant rats. Administration of oestrogen $6 \mathrm{~h}$ after ovariectomy significantly increased OTR mRNA in OVX pregnant rats to a level similar to that observed in $\mathrm{PGF}_{2 \alpha}$-treated rats and during spontaneous labour. However, oestrogen treatment failed to significantly increase the OTR mRNA in sham-operated (control) pregnant rats compared with vehicle-treated control pregnant rats. Thus, the removal of the ovary during pregnancy, as in this study, facilitated the action of oestrogen on OTR mRNA expression, indicating that some ovarian factor(s) suppressed the induction of OTR mRNA by oestrogen in pregnant rats. Taken together with the results of $\mathrm{PGF}_{2 \alpha}$ treatment, these results suggest that progesterone secreted from the corpora lutea during pregnancy suppresses the action of oestrogen, and that luteolysis coupled with the decline in serum progesterone levels may be necessary for the induction of OTR mRNA by oestrogen in parturition.

Two further possibilities which are not precluded from the result and require clarification are whether the effect of ovariectomy on oestrogen action is specific in pregnant rats and whether ovarian factor(s) other than progesterone are involved. Hence it was deemed necessary to determine whether the decline in progesterone levels prior to the increase in oestrogen level is important for the action of oestrogen in OVX virgin rats. A single administration of oestrogen increased OTR mRNA levels in OVX control rats, but this effect was suppressed by exposure to high levels of serum progesterone for 8 days in rats whose progesterone tubes were not removed. When the tubes containing progesterone were removed before oestrogen injection, the oestrogen treatment caused an increased OTR mRNA similar to the level observed in the oestrogen-only group. These results suggest that a decline in the progesterone level is necessary for the expression of the stimulatory effects of oestrogen on uterine OTR mRNA even in OVX virgin rats. Thus, although progesterone did not suppress the stimulatory effect of oestrogen on OTR mRNA when both steroids were concomitantly injected into OVX virgin rats (Larcher et al. 1995, Liu et al. 1996), our present observation showed that exposure to progesterone before the increase in oestrogen level in the circulation resulted in a suppression of oestrogen action on OTR mRNA expression.

The inhibitory effects of progesterone on OTR expression have been reported in OVX ewes (Leavitt et al. 1985, Lau et al. 1992, 1993, Zhang et al. 1992). The decline in serum progesterone levels in the presence of oestrogen resulted in OTR increases in OVX sheep (Leavitt et al. 1985, Zhang et al. 1992), accompanied by increased nuclear oestrogen receptor (ER) in both endometrium and myometrium while cytosolic ER and progesterone receptor (PR) increased only in endometrium (Leavitt et al. 1985). Progesterone also blocked oestrogen-induced ER gene expression and ER synthesis in non-pregnant sheep myometrium and endometrium (Wu et al. 1996b). Longterm treatment with progesterone in OVX sheep caused the down-regulation of PR (Vallet et al. 1990, Wathes et al. 1996b), followed by increased ER and OTR (Wathes et al. 1996b). Progesterone interferes with oestrogeninduced replenishment of uterine cytosolic ER in immature rats (Hsueh et al. 1976) and both cytosolic and nuclear ER in OVX rats (Zhou et al. 1993). Synthetic progestin increased ER turnover and blocked oestrogen-induced ER synthesis in hamster uterine decidual cells (Takeda \& Leavitt 1986). These effects of progesterone on ER regulation in the uterus may involve a suppressive effect of progesterone on oestrogen action in the OTR mRNA expression mentioned above. While RU486 (an antiprogesterone compound) treatment in late pregnant rats did not result in a significant increase in uterine cytosolic ER and ER mRNA levels (Fang et al. 1997), it increased cytosolic and nuclear ER in decidua and myometrium of rhesus macaques in late pregnancy (Haluska et al. 1990). Therefore, whether progesterone regulates uterine responsiveness to oestrogen by decreasing ER levels is not clear. 
However, the evidence that progesterone slightly inhibited the ovariectomy-induced increase in uterine ER mRNA levels in rats (Rosser et al. 1993) may support the hypothesis that progesterone may regulate uterine responsiveness to oestrogen by decreasing ER levels.

OTR mRNA expression in rats was detected in myometrium but not in endometrium (Larcher et al. 1995), while it was observed in sheep endometrium and myometrium (Wathes et al. 1996a) and in human myometrium, decidua and chorion (Takemura et al. 1994, Kimura et al.1996). Human OTR mRNA expression in the myometrium increased in late pregnancy while decidual expression did not rise at term. Sheep OTR mRNA expression increased at labour in endometrium and myometrium (Wathes et al. 1996a), but ER and PR are likely to be regulated differently in endometrium and myometrium in sheep (Leavitt et al. 1985). Thus, the regulation of OTR expression and the involvement of ovarian steroids appears to be different among tissues in different species. A further examination of the involvement of ovarian steroids is therefore necessary for a precise understanding of OTR regulation and the onset of parturition.

It has been shown that treatment with RU486 increased OTR mRNA expression in pregnant rat uterus (Fang et al. 1997) and ovariectomy in late pregnancy resulted in an increased OTR mRNA expression $48 \mathrm{~h}$ and $96 \mathrm{~h}$ afterwards; progesterone injection suppressed this increase (Ou et al. 1998). Thus, progesterone, in itself, has a suppressive effect on OTR mRNA expression in pregnant rats. The findings of the present study confirm this action of progesterone and further demonstrate that its action is already present at about $24 \mathrm{~h}$ after ovariectomy. It should be noted that OTR mRNA in $\mathrm{PGF}_{2 \alpha}$-treated pregnant rats also significantly increased $24 \mathrm{~h}$ after the treatment. It is conceivable, therefore, that the decline in progesterone levels results in the induction of OTR mRNA expression possibly through two different mechanisms. One is mediated via the stimulatory action of oestrogen in OTR mRNA expression and the other is independent of this stimulatory action. But whether, in the later mechanism, progesterone directly affects the OTR gene is difficult to say, because the promoter region of the rat OTR gene does not possess a consensus progesterone response element (Rozen et al. 1995, Bale \& Dorsa 1997). An apparent paradox is that this induction of OTR mRNA was not observed in OVX virgin rats after the removal of the tubes containing progesterone. Two plausible ideas may be proposed as an explanation of this disparity. First, a specific endocrine environment in late pregnancy is necessary for the expression of OTR mRNA induced by the removal of the ovaries. In this context, since administration of progesterone after ovariectomy in late pregnancy suppressed the effect of ovariectomy on OTR expression after $48 \mathrm{~h}$ and $96 \mathrm{~h}$ (Ou et al. 1998), the decline of progesterone in itself is a trigger for the expression. It is also possible that some factors derived from tissues other than the ovary, such as the placenta, fetus or uterus, appear to be involved in the induction of OTR mRNA. Secondly, a 1-week exposure to progesterone may not have been enough to simulate the effect of progesterone withdrawal on OTR mRNA expression. It has been reported that there is a difference in OT mRNA expression in the paraventricular nucleus of the rat hypothalamus as determined by in situ hybridisation between exposure to progesterone for 1 and 2 weeks (Amico et al. 1997). In $\mathrm{PGF}_{2 \alpha}$-deficient mice, ovariectomy also increased uterine OTR mRNA levels (Sugimoto et al. 1997), but the ratio of increase was much larger than that observed in this study. It is difficult to proffer a suitable explanation for this difference at present, but it may be due to the influence of $\mathrm{PGF}_{2 \alpha}$ deficiency on OTR mRNA expression or the species difference between rats and mice.

In summary, this study has demonstrated that both the decline of progesterone resulting from luteolysis and the increase in oestrogen in late pregnancy are important for the expression of OTR mRNA. Once luteolysis occurs, the OTR mRNA increases in a similar time-course. Moreover, $\mathrm{PGF}_{2 \alpha}$-treated pregnant rats, OVX pregnant rats, and steroid-treated OVX virgin rats together constitute appropriate models which may be useful in the attempt to gain full understanding of the mechanism(s) which regulate OTR synthesis and the onset of parturition in mammals.

\section{Acknowledgements}

We thank Dr Chuma Okere for reviewing this manuscript. This work was supported by the Yokoyama Foundation for Clinical Pharmacology and by a grant-inaid for Scientific Research from the Ministry of Education, Sports, Science and Culture of Japan.

\section{References}

Amico JA, Thomas A \& Hollingshead DJ 1997 The duration of estradiol and progesterone exposure prior to progesterone withdrawal regulates oxytocin mRNA levels in the paraventricular nucleus of the rat. Endocrine Research 23 141-156.

Bale TL \& Dorsa DM 1997 Cloning, novel promoter sequence, and estrogen regulation of a rat oxytocin receptor gene. Endocrinology 138 1151-1158.

Bridges RS 1984 A quantitative analysis of the roles of dosage, sequence, and duration of estradiol and progesterone exposure in the regulation of maternal behavior in the rat. Endocrinology 114 930-940.

Chomczynski P \& Sacchi N 1987 Single-step methods of RNA isolation by acid guanidinium thiocyanate-phenol-chloroform extraction. Analytical Biochemistry 162 156-159.

Crowley RS, Insel TR, O'Keefe JA, Kim NB \& Amico JA 1995 Increased accumulation of oxytocin messenger ribonucleic acid in 
the hypothalamus of the female rat: Induction by long term estradiol and progesterone administration and subsequent progesterone withdrawal. Endocrinology 136 224-231.

Fang X, Wong S \& Mitchell BF 1997 Effects of RU486 on estrogen, progesterone, oxytocin, and their receptors in the rat uterus during late gestation. Endocrinology 138 2763-2768.

Fuchs A-R, Periyasamy S, Alexandrora M \& Soloff MS 1983 Correlation between oxytocin receptor concentration and responsiveness to oxytocin in pregnant rat myometrium: Effects of ovarian steroids. Endocrinology 113 742-749.

Fuchs AR, Fuchs F, Husslein P \& Soloff MS 1984 Oxytocin receptors in the human uterus during pregnancy and parturition. American Journal of Obstetrics and Gynecology 150 734-741.

Grazzini E, Guillon G, Mouillac B \& Zingg HH 1998 Inhibition of oxytocin receptor function by direct binding of progesterone. Nature 392 509-512.

Haluska GJ, West NB, Novy MJ \& Brenner RM 1990 Uterine estrogen receptors are increased by RU486 in late pregnancy rhesus macaques but not after spontaneous labor. Journal of Clinical Endocrinology and Metabolism 70 181-186.

Higuchi T 1995 Oxytocin: A neurohormone, neuroregulator, paracrine substance. Japanese Journal of Physiology 45 1-21.

Hsueh AJW, Peck EJ Jr \& Clark JH 1976 Control of uterine estrogen receptor levels by progesterone. Endocrinology 98 438-444.

Kimura T, Takemura M, Nomura S, Nobunaga T, Kubota Y, Inoue T, Hashimoto K, Kumazawa I, Ito Y, Ohashi K, Koyama M, Azuma C, Kitamura Y \& Saji F 1996 Expression of oxytocin receptor in human pregnant myometrium. Endocrinology 137 780-785.

Larcher A, Neculcea J, Breton C, Arslan A, Rozen F, Russo C \& Zingg HH 1995 Oxytocin receptor gene expression in the rat uterus during pregnancy and the estrous cycle and in response to gonadal steroid treatment. Endocrinology 136 5350-5356.

Lau TM, Kerton DJ, Gow CB \& Fairclough RJ 1992 Increase in concentration of uterine oxytocin receptors and decrease in response to 13,14-dihydro-15-keto prostaglandin $\mathrm{F}_{2 \alpha}$ in ewes after withdrawal of exogenous progesterone. Journal of Reproduction and Fertility 95 885-893.

Lau TM, Kerton DJ, Gow CB \& Fairclough RJ 1993 Role of progesterone in the control of endometrial oxytocin receptors at luteolysis in sheep. Journal of Reproduction and Fertility 98 229-233.

Leavitt WW, Okulicz WC, McCracken JA, Schramm W \& Robidoux Jr WF 1985 Rapid recovery of nuclear estrogen receptor and oxytocin receptor in the ovine uterus following progesterone withdrawal. Journal of Steroid Biochemistry 22 687-691.

Liu C-X, Takahashi S, Murata T, Hashimoto K, Agatsuma T, Matsukawa S \& Higuchi T 1996 Changes in oxytocin receptor mRNA in the rat uterus measured by competitive reverse transcription-polymerase chain reaction. Journal of Endocrinology 150 479-486.

Maggi M, Genazzani AD, Giannini S, Torrisi C, Baldi E, di Tomasso M, Munson PJ, Rodbard D \& Serio M 1988 Vasopressin and oxytocin receptors in vagina, myometrium, and oviduct of rabbits. Endocrinology 122 2970-2980.

Maggi M, Peri A, Giannini S, Fantoni G, Guardabasso V \& Serio M 1991 Oxytocin and V1 vasopressin receptors in rabbit endometrium during pregnancy. Journal of Reproduction and Fertility 91 575-581.

Ou C-W, Chen Z-Q, Qi S \& Lye SJ 1998 Increased expression of the rat myometrial oxytocin receptor messenger ribonucleic acid during labor requires both mechanical and hormonal signals. Biology of Reproduction 59 1055-1061.

Rosser M, Chorich L, Howard E, Zamorano P \& Mahesh VB 1993 Changes in rat uterine estrogen receptor messenger ribonucleic acid levels during estrogen- and progesterone-induced estrogen receptor depletion and subsequent replenishment. Biology of Reproduction 48 89-98.

Rozen F, Russo C, Banville D \& Zingg HH 1995 Structure, characterization and expression of the rat oxytocin receptor gene. PNAS 92 200-204.

Soloff MS 1975 Uterine receptor for oxytocin: effects of estrogen. Biochemical and Biophysical Research Communications 65 205-212.

Soloff MS, Alexandrova M \& Fernstrom MJ 1979 Oxytocin receptors: triggers for parturition and lactation? Science 204 1313-1315.

Soloff MS, Fernstrom MA, Periyasamy S, Soloff S, Baldwin S \& Wieder M 1983 Regulation of oxytocin receptor concentration in rat uterine explants by estrogen and progesterone. Canadian Journal of Biochemistry and Cell Biology 61 625-630.

Sugimoto Y, Yamasaki A, Segi E, Tsuboi K, Aze Y, Nishimura T, Oida H, Yoshida N, Tanaka T, Katsuyama M, Hasumoto K, Murata T, Hirata M, Ushikubi F, Negishi M, Ichikawa A \& Narumiya S 1997 Failure of parturition in mice lacking the prostaglandin F receptor. Science 277 681-683.

Takeda A \& Leavitt WW 1986 Progestin-induced down regulation of nuclear estrogen receptor in uterine decidual cells: analysis of receptor synthesis and turnover by the density-shift method. Biochemical and Biophysical Research Communications 135 98-104.

Takemura M, Kimura T, Nomura S, Makino Y, Inoue T, Kikuchi T, Kubota Y, Tokugawa Y, Nobunaga T, Kamiura S, Onoue H, Azuma C, Saji F, Kitamura Y \& Tanizawa O 1994 Expression and localization of human oxytocin receptor mRNA and its protein in chorion and decidua during parturition. Journal of Clinical Investigation 93 2319-2323.

Vallet JL, Lamming GE \& Batten M 1990 Control of endometrial oxytocin receptor and uterine response to oxytocin by progesterone and oestradiol in the ewe. Journal of Reproduction and Fertility $\mathbf{9 0}$ 625-634.

Wathes DC, Smith HF, Leung ST, Stevenson KR, Meier S \& Jenkin G 1996a Oxytocin receptor development in ovine uterus and cervix throughout pregnancy and at parturition as determined by in situ hybridization analysis. Journal of Reproduction and Fertility 106 23-31.

Wathes DC, Mann GE, Payne JH, Riley PR, Stevenson KR \& Lamming GE $1996 b$ Regulation of oxytocin, oestradiol and progesterone receptor concentrations in different uterine regions by oestradiol, progesterone and oxytocin in ovariectomized ewes. Journal of Endocrinology 151 375-393.

Wu WX, Verbalis JG, Hoffman GE, Derks JB \& Nathanielsz PW 1996a Characterization of oxytocin receptor expression and distribution in the pregnant sheep uterus. Endocrinology 137 722-728.

Wu WX, Owiny J, Zhang Q, Ma XH \& Nathanielsz PW 19966 Regulation of the estrogen receptor and its messenger ribonucleic acid in the ovariectomized sheep myometrium and endometrium: the role of estradiol and progesterone. Biology of Reproduction $\mathbf{5 5}$ 762-768.

Zhang J, Weston PG \& Hixon JE 1992 Role of progesterone and oestradiol in the regulation of uterine oxytocin receptors in ewes. Journal of Reproduction and Fertility 94 395-404.

Zhou Y, Chorich LP, Mahesh VB \& Ogle TF 1993 Regulation of estrogen receptor protein and messenger ribonucleic acid by estradiol and progesterone in rat uterus. Journal of Steroid Biochemistry and Molecular Biology 46 687-698.

Received 9 November 1999

Revised manuscript received 8 February 2000

Accepted 24 February 2000 